\title{
Care demands experienced by family caregivers of children with Primary Immunodeficiency
}

\author{
Demandas de cuidados vivenciadas por cuidadores familiares de crianças com Imunodeficiência Primária \\ Cuidado demanda experimentado por familiar cuidadores de niños con Inmunodeficiencia Primaria
}

\section{Milka Gabrielle de Lira Nóbrega West' ORCID: 0000-0002-0789-7004 \\ Maria Gorete Lucena de Vasconcelos' ORCID: 0000-0001-7226-1646 \\ Maria Wanderleya de Lavor Coriolano-Marinus' ORCID: 0000-0001-7531-2605 \\ Ednaldo Cavalcante de Araújo ORCID: 0000-0002-1834-4544}

'Universidade Federal de Pernambuco. Recife, Pernambuco, Brazil.

How to cite this article: West MGLN, Vasconcelos MGL, Coriolano-Marinus MWL, Araújo EC. Care demands experienced by family caregivers of children with Primary Immunodeficiency. Rev Bras Enferm. 2020;73(Suppl 4):e20180795. doi: http://dx.doi.org/10.1590/0034-7167-2018-0795

Corresponding author:

Milka Gabrielle de Lira Nóbrega West E-mail:milkanobrega@gmail.com

EDITOR IN CHIEF: Dulce Barbosa ASSOCIATE EDITOR: Priscilla Broca

Submission: $10-15-2018$

Approval: 01-22-2020

\begin{abstract}
Objective: to understand the experiences of family caregivers of children with Primary Immunodeficiency in view of care demands. Methods: a qualitative research. Data collection was subsidized by an open interview with five family caregivers, and the data were analyzed using the Bardin Content Analysis technique, thematic modality. The Callista Roy's Adaptation Model of Nursing was used to interpret the data. Results: from participants' reports, the following categories emerged: Maternity: facing adversity; Remodeling of daily life; The Social Support Network resource. Final considerations: family caregivers experience several feelings such as anguish and low self-esteem due to the fear of losing their child and the routine of illnesses and hospitalizations, in addition to needs that are often not reached due to incompatibility with the family budget. The Social Support Network is strengthened for most caregivers, playing an essential role as a coping strategy for caregivers.

Descriptors: Immunity; Caregives; Family. Children; Adaptation.
\end{abstract}

\section{RESUMO}

Objetivo: compreender as vivências dos cuidadores familiares de crianças com Imunodeficiência Primária frente às demandas de cuidados. Métodos: pesquisa de abordagem qualitativa. A coleta de dados foi subsidiada por entrevista aberta com cinco cuidadores familiares, e os dados foram analisados pela técnica de Análise de Conteúdo de Bardin, modalidade temática. Utilizou-se o Modelo de Adaptação de Callista Roy para interpretação dos dados. Resultados: a partir dos relatos dos participantes, emergiram as seguintes categorias: Maternidade: enfrentamento das adversidades; Remodelação do cotidiano; O recurso da Rede de Apoio Social. Considerações finais: os cuidadores familiares vivenciam múltiplos sentimentos, como angústia e baixa autoestima pelo medo da perda do filho e pela rotina de adoecimentos e hospitalizações, além de necessidades, muitas vezes, não alcançadas pela incompatibilidade em relação ao orçamento familiar. A Rede de Apoio Social mostra-se fortalecida para a maioria dos cuidadores, exercendo papel essencial enquanto estratégia de enfrentamento para os cuidadores.

Descritores: Imunidade; Cuidadores; Família; Criança; Adaptação.

\section{RESUMEN}

Objetivo: comprender las experiencias de los cuidadores familiares de niños con Inmunodeficiencia Primaria frente a las demandas de cuidado. Métodos: enfoque cualitativo de investigación. La recolección de datos fue subsidiada por una entrevista abierta con cinco cuidadores familiares, y los datos fueron analizados utilizando la técnica de Análisis de Contenido de Bardin, modalidad temática. El modelo de adaptación Callista Roy se utilizó para interpretar los datos. Resultados: de los informes de los participantes, surgieron las siguientes categorías: Maternidad: afrontamiento de la adversidad; Remodelación de la vida diaria; Recurso de la Red de Apoyo Social. Consideraciones finales: Ios cuidadores familiares experimentan múltiples sentimientos, como angustia y baja autoestima debido al miedo a perder a su hijo y la rutina de enfermedades y hospitalizaciones, además de las necesidades que a menudo no se alcanzan debido a la incompatibilidad con el presupuesto familiar. La Red de Apoyo Social se fortalece para la mayoría de los cuidadores, desempeñando un papel esencial como estrategia de afrontamiento para los cuidadores.

Descriptores: Inmunidad; Cuidadores; Familia; Niño; Adaptación. 


\section{INTRODUCTION}

Primary Immunodeficiencies (PIDs) form a group of genetic diseases resulting from failures in the development, maturation and function of immune cells. Secondary manifestations such as infections, autoimmune and oncological diseases are present in the affected children. Most of the time, diagnosis occurs in childhood, and causes, in addition to infectious conditions, repercussions such as delayed linear growth, poor response to routinely used antibiotics, increased frequency and duration of hospitalizations and mortality ${ }^{(1-2)}$.

PIDs consequences and treatment can also cause the child and the family, especially the family caregiver, changes in daily life, due to the frequency of multidisciplinary consultations, restriction of environments to protect children and frequent hospitalizations, factors responsible, in many cases, for causing emotional problems, social isolation and family breakdown, so they demand mechanisms to adapt to the routine $e^{(3)}$.

When considering the need for family adaptation to the issues raised for children and families living with PIDs, Callista Roy's Adaptation Model of Nursing was chosen to elucidate the daily life of caregivers who experience the care experience for children with PID.

Callista Roy's Adaptation Model of Nursing considers the person as an individual, family or community as a system that, when receiving internal and external encouragement, mobilizes the mechanisms of physiological coping, self-concept, role function and interdependence, which result in behaviors adaptive or ineffective. The behavior that contributes to person integrity, in terms of survival, reproduction, well-being and dominance, is considered adaptive; and therefore, ineffective one who does not contribute or destroy integrity ${ }^{(4)}$.

Coping and adapting to adversity, especially by family caregivers, are continuous processes and directly related to environmental encouragement, personal characteristics and the presence of an informal Social Support Network, such as family and formal structure. This network is composed of health professionals, such as nurses who, through health education actions, can help family caregivers adjust to living with PID and thus provide better quality care for children, families and for themselves ${ }^{(4-5)}$.

Nurses have the role of caring for people, with regard to their health, by implementing the Nursing Process, which, according to Callista Roy's Adaptation Model of Nursing, must be carried out through the assessment of internal encouragement or personal factors and also by external factors, of which environmental factors stand out. The analysis of these factors subsidizes the nursing diagnoses, according to the needs found, and from them, interventions and the assessment of the entire process can be traced, with the purpose of achieving adaptive behavior( ${ }^{(4)}$.

Based on the challenges faced by the families of children living with PID, the study sought to answer the following research question: "How are the care demands experienced by family caregivers of children with Primary Immunodeficiency?".

There are gaps in knowledge regarding PIDs characteristics and how to deal with daily and emergency situations with problems arising from children's disease, treatment or care, in addition to the lack of knowledge of their own rights as users of health services.
In addition, studies that relate daily care practices (self-performed or delegated to another) to people with PID are scarce, although the impact caused by the responsibility of caring for children with immunodeficiencies in the lives of caregivers, represents a decisive factor in the treatment and can contribute to the expansion of care for children/families facing these challenges ${ }^{(6-10)}$.

\section{OBJECTIVE}

To understand the experiences of family caregivers of children with PID in view of care demands.

\section{METHODS}

\section{Ethical aspects}

In accordance with Resolution number 466/12 of the Ministry of Health, which deals with research involving human beings, after approval by the Research Ethics Committee of CCS/UFPE, with CAAE (Certificado de Apresentação para Apreciação Ética - Certificate of Presentation for Ethical Consideration), data collection started with an open interview, after free and informed consent from participants.

\section{Type of study}

This is a descriptive and exploratory study with a qualitative approach, developed in a University Hospital located city of Recife, state of Pernambuco, Brazil, in April 2016, with five family caregivers of children with PID and on regular human immunoglobulin replacement. Regular replacement of human immunoglobulin is necessary to compensate for lack of production or insufficient production. It takes place between 21 and 30 days, in a hospital environment, which promotes changes in the lifestyle and family dynamics of the affected children and caregivers, a fact responsible for redesigning the roles in view of the child's needs ${ }^{(3)}$.

During the data collection period, there were five children with PID regularly monitored at the allergology outpatient clinic. Therefore, in order to build ideas about the care experience of all people eligible for the research, in compliance with the realities pointed out, the five family caregivers were interviewed.

To structure this study, the COREQ script (consolidated criteria for qualitative research reports) was applied. This tool presents a checklist with 32 items to report interviews and focus groups. The checklist has specific items to describe qualitative studies and assists researchers in the study methods and context, results, analysis and interpretations ${ }^{(11)}$.

\section{Methodological procedures}

\section{Study setting}

The study was carried out at the allergology outpatient clinic of a University Hospital located in the city of Recife, state of Pernambuco, in April 2016.

The allergology outpatient clinic is intended for care for people with suspicion or confirmation of allergic diseases, by prior appointment, by medical referral from the various public health 
services in the state of Pernambuco or outside it. In this service, pediatric patients are assisted once a week with care focused on PIDs and recurrent diseases.

\section{Data source}

Data collection took place from potential research participants. During the data collection period, there were five children with PID regularly monitored at the allergology outpatient clinic. Therefore, aiming at building knowledge about the care experience of all people eligible for the research, the five family caregivers were interviewed. Family caregivers of children with PID, undergoing treatment with regular use of intravenous human immunoglobulin, were included in the said service, aged 18 years or older. Escorts of children who were not regular caregivers or who were for less than three months were excluded.

\section{Collection and organization of data}

Initially, identification data and related to the sociodemographic profile were collected. The open questions were led by the following guiding question: what is it like to care for children with this disease (PID)?

In order to achieve the objective of this study, when necessary, free response questions were asked, such as: how is your daily life? Do you get help from someone? Were there changes in your life due to care for children with PID?

During the interviews, a digital voice recorder model SAMSUNG WIN GT18552B was used ${ }^{\mathrm{TM}}$. All took place in a reserved place at the allergology outpatient clinic of the University Hospital, in order to guarantee participant privacy, minimize noise and avoid interruptions. At the time, only the interviewer and the caregiver were present, so that they could express themselves freely, with confidentiality maintained ${ }^{(12)}$. Interview duration ranged according to the needs of each participant and presented an average time of 14 minutes. In order to preserve participants' privacy, they had their identity coded with the alphanumeric initials C01, $\mathrm{CO} 2, \mathrm{CO}, \mathrm{CO} 4$ and C05.

\section{Data analysis}

The interviews were transcribed, forming the corpus of analysis. It was analyzed using Bardin's Content Analysis technique, in the thematic modality. In this perspective, the data analysis proceeded in three stages: the first, pre-analysis, consisted of the transcription of the interviews, to systematize the initial ideas, with the identification of the nuclei of meaning (selection of excerpts from the sentences, with the composition of descriptive codes); the second stage comprised the identification of the classification units, with clipping of the reports, classification and aggregation of the units of meaning (interpretation, with creation of subcategories); later, categorization took place, which correlated perceptions and events in an orderly manner. The third stage was elaborated by the articulation of the excerpts and categories of the reports, the scientific evidence on the theme and the making of inferences and interpretations ${ }^{(13)}$ in the light of Callista Roy's Adaptation Model of Nursing.

\section{RESULTS}

Five caregivers participated in the study, whose ages varied between 29 and 39 years, all of whom were mothers of children with PID. Regarding marital status, two were married, one lived in consensual union, one was separated and one was single. Regarding education, three had 12 years of study and two, eight years. Regarding family income, the five families lived on a minimum wage and none of the children received financial benefits due to PID. Among the children, three were only children and two with siblings under 18 years of age and the ages of the children ranged from three to 10 years.

Callista Roy's Adaptation Model of Nursing states that the person in the face of adversity has the ability to adapt and change the environment, in order to contribute to the search or maintenance of their physical and psychological health and to collaborate with social well-being. Despite the segmentation of Callista Roy's Theory systems into Person, Environment and Health. They cannot be seen, but integrated, since they are dynamic, interact with each other and influence the growth, development and biopsychosocial relationships of people and groups ${ }^{(4)}$.

From caregivers' experiences, three themes were identified, didactically grouped in Callista Roy's Theory of Adaptation systems (Figure 1).

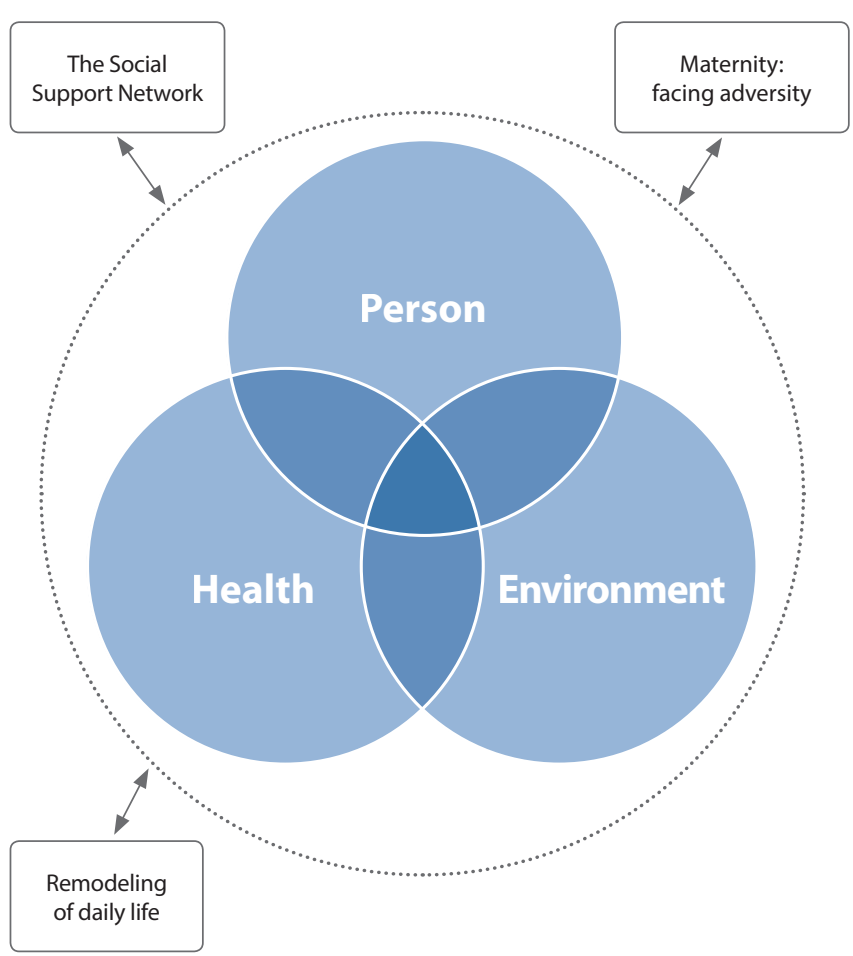

Figure 1 - Categories of care demands experienced by family caregivers of children with Primary Immunodeficiency and Callista Roy's adaptation systems, 2016

\section{Category 1: Maternity: facing adversity}

The role of motherhood is complex and involves the continuous provision of care to ensure children's well-being. In situations where there is a diagnosis of a chronic condition such as PID in 
children, care is intensified and, at various times, mothers report the burden due to hospitalizations, fear of the child's illness and anguish for not being able to avoid situations of illness.

His fever started yesterday out of nowhere, but it already made me sicker than he did, I didn't sleep, I was worried. (C01)

[...] my life was always only in the hospital, I spent ten days in the hospital, came home, then he started to get sick again. (C01)

[...] but it's complicated, because he needs respiratory physiotherapy, so I can't do it for the public [service]. I tell you, because I already walked, I already left several physiotherapy referrals and I can't get physical therapy. (C03)

Care and concern with the children's illness end up being perceived by others as exaggeration, but the fear of experiencing similar illness situations imposes a continuous surveillance routine.

Everyone says it is exaggerated care, I say no! Be careful, not least because it was a big dream to be a mother, my first one I don't know if I was a boy, if I was a girl, I didn't have the opportunity [...]. (C01)

He already went to the ICU, he was nebulized every 20 minutes, you know, he was going to be intubated ... sometimes, I think I do so little. (CO3)

One of the factors reported that contributes to greater adaptation and empowerment is the search for knowledge and care related to PID, its implications and ways of preventing illness situations. This knowledge is reflected in actions that favor family adaptation to the new reality and, therefore, the provision of the most appropriate care for the child.

I want to know what it is ... I went to search the internet. I have no doubt, when I have it, I go and ask everything. (C02)

[...] because I come to the doctor, talk to the doctors, I understand everything ... from time to time there is a lecture, then we watch, listen, then understand. (C05)

Despite the challenges arising from the care of children with PID, caregivers have, as a common characteristic, the ability to follow life, overcoming the adversities imposed on their daily life and family life and not restricting themselves to the limitations of their children, but recognizing them as children who can have a school life, with cognitive and social learning.

Once you know [the diagnosis], just do the treatment and get on with life, right? (CO2)

[...] when we are a mother, we resist to everything. (C03)

lembark on my children's dreams. They can and will be whatever they want. (C03)

[...] since last year he studies, his own will ... his father was against putting him in school ... lencourage him at school even more...(C01)

\section{Category 2: Remodeling of daily life}

The routine permeated by home care and frequent visits to consultations and hospitalizations, in search of immune stability and prevention of secondary diseases, in addition to carrying out household chores results in overload in caregivers' daily lives, modifications and abdications from personal activities and work to provide care for children with PID.

\section{Before I worked at school, I worked every day. Today it is different} because of consultations, her hospitalizations. (C02)

I stopped working, because it was a month and another was missing, due to the comings and goings from the hospital. (C03)

I worked and stopped working when he started treatment. (C04)

In addition, the family budget is not always compatible with care and actions aimed at the pursuit and maintenance of a healthy life. They include basic needs for the family, such as food and leisure, as well as public transport costs for attending multidisciplinary services, physical activity and sports.

[...] it's kind of unpredictable, right, but sometimes like that, my sister needs it, I go there, I wash her clothes, she gives me 20, 30 reais [reais is the Brazilian currency] ... (C02)

It really is very expensive and so, for a single person who works at home, to maintain everything is very complicated. I tried to put him on the benefit, but they said I had no right because of, because they are ... have a minimum wage. (C03)

\section{Category 3: The Social Support Network resource}

The provision of continuous care by caregivers favors a deeper understanding of the child's daily and individual needs and the promotion of greater social and family life. Caregivers need help to continue to carry out the chores that involve child care and personal activities. Such help is commonly provided by the spouse and extended family, whose help represents the personal resources in which they feel most confident.

$[\ldots]$ when it is the night he arrives from the service [...] he helps me. (C01)

\section{[...] my husband helps me; he is more careful than me. (C05)}

When I need to go out, my mother will stay with him and, therefore, he is as careful as I am. (CO4)

Thankgoodness, sheis well received at home. Mymotherhelpsme... (C02)

Everyone in my family knows about the diagnosis, care and support. The family is very supportive. (C05)

Although four participants addressed the support received, one of the interviewees reported not receiving any support for care related to children with PID.

\section{[...] I have no help from anyone and nothing. (C03)}

Among others, the support offered by health professionals was also recognized as important for promoting understanding of the disease, conduction, cooperation and support to the child in his new daily life and for the reconstruction of projections about the child and his family life. This support must be present from the first contact, making a welcoming service. 
He did not get sick, because at four months he already took immunoglobulin, because he already investigated because of my nephew. He never had pneumonia, these things. (C04)

The nurses all here and down there, the doctors are very good, they are excellent. They try to make the most. (C03)

\section{DISCUSSION}

Mothers, historically and socially, are the person who take care of the sick child, becoming the main caregivers, experiencing several changes in their life. Their emotional impact is expressive, because several feelings are experienced, such as too much responsibility, suffering and fear, in addition to suffering the cultural pressure to exercise uninterrupted and, at times exhaustive, care for a child with a chronic disease ${ }^{(14)}$. In view of the above, caregivers need to adapt to the new care demands for children with PID.

Callista Roy, in her adaptation model, understands that the goal of nursing is to promote the adaptation of the person, be it, individual, family or community, in the four adaptive modes ${ }^{(4)}$. Thus, the role of the nurse can contribute to the health of the family caregiver and the quality of care provided by the child.

The data indicate that the exercise of motherhood in care for children with PID is permeated by anguish, fear and suffering in the face of hospitalizations, daily preventive care to prevent infections. This understanding may expand the scope of work of professionals who deal with the care of children with chronic diseases and the various changes/adaptations necessary for the family routine.

The caregiver's behavior shows a response to the encouragement received by him and that mobilizes personal coping mechanisms, which can be innate or acquired to respond to the new routine. Encouragement can be internal or external and considered focal, when they confront the person and provoke an immediate reaction, contextual, those that influence focal encouragement and portray the reality in which the person is inserted, or even residual, that are not perceived by the person, but influence other encouragement ${ }^{(4)}$.

Encouragement and behavior effectiveness, from the point of view of adaptation, can be seen from the adaptive modes, which interact, affect each other, in situations where they are ineffective. The physiological mode is related to functions such as oxygenation, feeding, elimination, protection, activity and rest ${ }^{(4)}$. For most caregiving mothers, according to reports of difficulty in performing rest and activities not directly related to children with PID, this mode is ineffective.

In line with the findings in this study, the caregiver who experiences chronic disease in childhood has difficulty adapting in the self-concept mode, due to the abdication of personal and professional activities in children care. The self-concept mode, the physical self, is the way in which the person sees himself in relation to appearance, state of health and the perception of sexuality and the personal self, it is a form of self-perception and self-awareness ${ }^{(4)}$.

The process of illness and hospitalization, especially in childhood, generates a great psychological impact on family members, especially the mother and the child, such as the disorganization in perception, understanding and emotion. This weakens the ability of maternal care and establishes, in some cases, regression in the child's psychological development ${ }^{(15)}$.
According to the reports of the caregiving mothers, rehospitalizations, prolonged hospital stay and the treatment of PID generate feelings such as anguish and suffering in them and in children due to the inability to plan for the future and fear of death. The loss of the child, especially as a child, is one of the greatest fears faced by the parents, since it does not follow the natural and chronological order of life, a fact that generates in these people an intense feeling of guilt, helplessness and lack of motivation to follow their own life. Such emotions arise more strongly in cases of only children due to the perceived closure of the offspring ${ }^{(16)}$.

The role or role performance is related to the person's primary, secondary and tertiary roles in the social environment, strongly influenced by cultural, gender, age and experience factors. In addition to the daily care demands, the performance of the roles played by caregivers is interpreted as ineffective, from an adaptive perspective ${ }^{(4)}$. Activities such as paid work and leisure occur unsatisfactorily or are abandoned to the detriment of the care needs of the child with PID, as exposed by the caregiving mothers.

Caring for children with special health needs requires, from the first manifestations of the disease and for life, additional effort on the part of the caregiver, which supersedes the usual support for the child without such demands. Caregivers role becomes central in the lives of these mothers who tend to value the child's needs in the first place, and therefore leave their own needs in the background and fragilely perform roles that are not directly related to care for children with chronic disease ${ }^{(17)}$. In this context, overload becomes a reality in the daily lives of caregiving mothers, due to taking all the culturally imposed responsibility for activities inherent to the home and caring for children with chronic disease. The repercussion of the burden on caregivers' life culminates in ineffective physiological adaptation, with consequent acute and chronic physical disorders, maladjustments in self-concept, isolation, depression and guilt, in addition to dysfunctions of interdependence, providing lower quality care to children and themselves ${ }^{(18)}$, according to reports found in this study.

The care demands imposed by the chronic disease cause numerous implications in family life, many of them occur suddenly, mainly for the caregiver and require adaptations and readaptations that cause effects in different aspects of life, from private to social. Financial imbalance, for example, caused by the expenses and implications of the disease, imposes little or no space for moments of leisure and distraction on the family group. It promotes changes in the judgment of situations, of others, but, above all, of themselves, which favors personal conflicts, such as the feeling of helplessness and low self-esteem and the difficulty in strengthening themselves in support networks $s^{(4,19-20)}$.

The mode of interdependence is the way in which the person interacts with his own environment, through the formation and strengthening of affective bonds, Social Support Networks and receptive behaviors ${ }^{(4)}$. Such interaction is established by the interpersonal relationships between those who help and those who are helped. Considered formal, the support network is made up of groups or institutions and people who play a role in society, such as health professionals. Meanwhile, informal social support is made up of people with whom you have contact or personal involvement, such as family, neighbors and friends ${ }^{(21)}$. 
Social group support, essentially the family, becomes essential for chronic disease acceptance in childhood and facing it during its course and long-term adaptation, being seen as the main source of support. In line with this research, family relationships contribute to the determination of interdependence as a coping mechanism and are characterized as true. They promote confidence in the resolution or to alleviate the adversities, by minimizing or even avoiding the feeling of burden for the caregiver ${ }^{(4,22)}$.

Increasingly frequent, the father's involvement in carrying out activities inherent to home and caring for children, especially when they have a chronic disease, is essential for the reorganization and adaptation of family dynamics, as reported by two of the five caregivers interviewed ${ }^{(23)}$.

For some family caregivers, the Social Support Network becomes weakened, if they take care of themselves. Support from extended family members and health professionals who follow up children were also mentioned. The lack of support can lead continuous caregivers to physical and mental exhaustion, in addition to social isolation, and as reported by one of the caregivers, who is without an informal support network, can negatively reflect on the quality of care provided to children ${ }^{(24)}$.

Health professionals can contribute to family adaptation in the face of living with the disease through multiple actions, as clear provision of information about children's health-disease process, caregivers' confidence encouragement and other family members, and provision of home care, established from the understanding of the reality of families, their peculiarities, potentialities and coping mechanisms adopted ${ }^{(25-26)}$.

One of the intervention actions to be performed by health professionals, especially by nurses, whose focus is on personcentered care, is to recognize the subjective dimensions affected by families that lives with children with chronic disease. Health education is a relevant tool to support the development and reelaboration of knowledge, knowledge and practices related to the reality of each individual and/or group about healthy living ${ }^{(27)}$.

It is through health education that nurses build a routine of care with the caregiver aimed at improving the quality of life of children with PID through the sharing between scientific and popular knowledge experienced by these children and their families ${ }^{(21)}$.

In this perspective, nurses must establish a dialogue with the caregiver, so as to provide clarification of questions and encourage autonomy and confidence in carrying out care and life habits, which contributes to comprehensive care in child care ${ }^{(21)}$.

Although adaptive modes are constantly encouraged and ineffectively adapted, it is in the face of adversity and potential that the caregiver has the opportunity to reflect and restructure her roles ${ }^{(28)}$. The family, especially the caregiving mothers of the present study, live with the disorders caused by the chronic disease, but do not allow themselves to surrender to them. As they have a moral duty to protect their children, caregivers define and redefine their lines of coping as overcoming strategies, in order to alleviate suffering, and hope and confidence in the realization of their children's personal projects also emerge ${ }^{(29)}$.

\section{Study limitations}

As this is a study involving caregivers of children with a rare disease, such as PID, the study population was reduced and, therefore, the results obtained for all scenarios of care for children with chronic diseases cannot be generalized.

\section{Contributions to nursing, health and public policies}

The contributions generated by this study are related to the understanding of the needs required from caregivers to avoid or decrease health status impairment of children with PID. This occurs when seeking support in structuring the nursing process in order to contemplate individuals, according to the needs pointed out during the scientific investigation. It is expected to promote greater visibility and reflection on the effective ways of adapting to care demands of children and families who live with PID.

\section{FINAL CONSIDERATIONS}

Family caregivers, especially mothers, as they are, in general, the main caregiver, experience, in daily life, various feelings, such as anguish, suffering, impotence and low self-esteem due to the fear of losing their child and due to the routine of illnesses and hospitalizations, in addition to needs that are often not met due to incompatibility with the family budget.

As for the Social Support Network, it is shown to be strengthened for most caregiving mothers, as there is an understanding and assistance in the provision of care for children with PID by the spouse and extended family and the reception by health professionals who follow them up, in addition to playing an essential role in the coping strategy by mothers.

Although adaptation processes are often ineffective in the physiological adaptive mode, in self-concept and in the role function, caused by the care demand for children with PID for many caregiving mothers, the mode of interdependence proved to be adapted for most from them. This aspect is, therefore, demonstrating the importance of the support network in the daily life of those who care for.

\section{REFERENCES}

1. Errante PR, Perazzio SF, Frazão JB, Silva NP, Andrade LEC. Associação da Imunodeficiência Primária com lúpus eritematoso sistêmico: revisão de literatura e as lições aprendidas pela Divisão de Reumatologia de um hospital universitário terciário em São Paulo. Rev Bras Reumatol. 2016;56(1):58-68. doi: 10.1016/j.rbr.2015.03.002

2. Roxo-Jr P. Gammaglobulin for primary immunodeficiency: when should it be used? when should it be used? Rev Med(Ribeirão Preto) [Internet]. 2014 [cited 2015 Sep 22];47(1):5-9. Available from: http://revista.fmrp.usp.br/2014/vol47n1/REV_Gammaglobulin\%20for\%20Primary\%20 Immunodeficiency.pdf 
3. Salvador MS, Gomes GC, Oliveira PK, Gomes VLO, Busanello J, Xavier DM. Estratégias de famílias no cuidado a crianças portadoras de doenças crônicas. Texto Contexto Enferm. 2015;24(3):662-669. doi: 10.1590/0104-07072015000300014

4. Roy C, Andrews HA. Teoria da Enfermagem: o Modelo de Adaptação de Roy [Tradução Clara Fonseca], Lisboa: Editora Instituto Piaget; 2000. 520p.

5. Coelho SMS, Mendes IMDM. Da pesquisa à prática de enfermagem aplicando o modelo de adaptação de Roy. Esc Anna Nery. 2011;15(4):845-50. doi: 10.1590/S1414-81452011000400026

6. Abolhassami H, Aghamohammadi A, Pourjabbar S, Salehi SM, Nikayin S, Rabiee A et al. Psychiatric aspects of primary immunodeficiency diseases: the parental study. Iran Journal Allergy Asthma Immunol [Internet] 2013. [cited 2015 Oct 22];12(2):176-81. Available from: http:// ijaai.tums.ac.ir/index.php/ijaai/article/10.1007\%2Fs10875-008-9180-9

7. Fasth $\mathrm{A}$, Nystrom J. Quality of life and health-care resource utilization among children with primary immunodeficiency receiving home treatment with subcutaneous human immunoglobulin. J Clin Immunol. 2008;28:370-378. doi: 10.1007/s10875-008-9180-9

8. Piazza-Waggoner C, Adams CD, Muchant D, Wilson NW, Hogan MB. Coping and adjustment in children with primary immunodeficiency disorders and kidney diseases: the role of illness severity. Children Health Care's. 2008;37:210-224. doi: 10.1080/02739610802151555

9. Piazza-Waggoner C, Adams CD, Muchant D, Wilson NW, Hogan MB. Children with primary immunodeficiency disorders: family functioning, coping strategies and behavioral functioning. Ann Allergy Asthma Immunol. 2006;3(3):191-208. doi: 10.1207/s15326888chc3503_1

10. Piazza-Waggoner C, Adams CD, Conttrell L, Taylor BK, Wilson NW, Hogan MB. Child and caregiver psychosocial functioning in pediatric immunodeficiency disorders. Ann Allergy, Asthma Immunol. 2006;96:298-303. doi: 10.1016/S1081-1206(10)61239-2

11. Tong A, Sainsbury P, Craig J. Consolidated criteria for reporting qualitative research (COREQ):a 32 item checklistfor interviews and focal group. Int J Qual Heath Care. 2007;19(6):349-357. doi: 10.1093/intqhc/mzm042

12. Ministério da Saúde (BR). Conselho Nacional de Saúde. Resolução N. 466, de 12 de Dezembro de 2012. [Internet] 2012[cited 2015 Oct 22]. Available from: http://bvsms.saude.gov.br/bvs/saudelegis/cns/2013/res0466_12_12_2012.html

13. Bardin L. Análise de Conteúdo. São Paulo: Editora Edições 70; 2011. 229p.

14. Colesante MFL, Gomes IP, Morais JD, Collet N. Impacto na vida de mães cuidadoras de crianças com doenças crônicas. Rev Enferm UERJ. 2015;23(4):501-6. doi: 10.12957/reuerj.2015.4966

15. Silva RCC, Sampaio JA, Ferreira AGN, Ximenes Neto FRG, Pinheiro PNC. Sentimento das mães durante hospitalização dos filhos: estudo qualitativo. Rev Soc Bras Enferm Ped [Internet]. 2010[cited 2016 Jun 13];10(1):23-30. Available from: http://www.sobep.org.br/revista/ images/stories/pdf-revista/vol10-n1/v.10_n.1-art3.pesq-sentimentos-das-maes-durante-hopitalizacao.pdf

16. Finelli LAC, Silva KJ, Santana MR. Percepção da mãe quanto às consequências que o câncer do filho traz ao relacionamento conjugal. RBPeCS [Internet]. 2015 [cited 2016 Jun 13];2(1):18-21. Available from: http://www.icesp.br/revistas-eletronicas/index.php/RBPeCS/article/view/27

17. Maia SDB. O bem-estar dos pais cuidadores de filhos adultos portadores de deficiência[Dissertação] [Internet]. Universidade de Lisboa. 2010[cited 2016 Jun 15]. Available from: http://repositorio.ul.pt/bitstream/10451/2743/1/ulfp037554_tm.pdf

18. Macedo EC, Silva LR, Paiva MS, Ramos MNP. Sobrecarga e qualidade de vida de mães de crianças e adolescentes com doença crônica: revisão integrativa. Rev Latino-Am Enferm. 2013;23(4):769-77. doi: 10.1590/0104-1169.0196.2613

19. Nóbrega VM, Reichert APS, Silva KL, Coutinho SED, Collet N. Imposições e conflitos no cotidiano de famílias de crianças com doenças crônicas. Esc Anna Nery. 2012; 16(4):781-8. doi: 10.1590/S1414-81452012000400020

20. Luz GS, Silva MRS, DeMontigny F. Doenças raras: intinerário diagnóstico e terapêutico das famílias das pessoas afetadas. Acta Paul Enferm. 2015;28(5):395-400. doi: 10.1590/1982-0194201500067

21. Floriano LA, Azevedo RCS, Reiners AAO. Cuidador familiar de idosos: a busca pelo apoio social formal e informal. Cienc Cuid Saúde. 2012; 11(1):18-25. doi: 10.4025/cienccuidsaude.v11i1.18854

22. Silveira CL, Budó MLD, Garcia RP, Silva FM, Simon BS. Cuidar de familiar com doença crônica incapacitante: implicações na rede social de apoio. J Nur Health [Internet] 2014. [cited 2016 Jul 11];4(10):39-50. Available from: https://periodicos.ufpel.edu.br/ojs2/index.php/enfermagem/article/ view/4404/3507

23. Polita NB, Alvarenga WA, Leite ACAB, Araújo JS, Santos LBPA, Zago MMF, et al. Cuidado paterno ao filho com câncer sob influencia das masculinidades: metassíntese qualitativa. Rev Bras Enferm. 2018; 71(1):185-194. doi: 10.1590/0034-7167-2016-0671

24. Araújo YB, Reichert APS, Vasconcelos MGL, Collet N. Fragilidade da rede social de famílias de crianças com doença crônica. Rev Bras Enferm. 2013;66(5):675-81. doi: 10.1590/S0034-71672013000500006

25. Rodrigues PF, Amador DD, Silva KL, Reichert APL, Collet N. Interação entre equipe de enfermagem e família na percepção dos familiares de crianças com doenças crônicas. Esc Anna Nery. 2013;17(4):781-787. doi: 10.5935/1414-8145.20130024

26. Sousa EFR,Costa EAO, Dupas G, Wernet M. Acompanhamento de família de crianças com doenças crônicas: percepção da equipe de Saúde da Família. Rev Esc Enferm USP. 2013;47(6):1367-72. doi: 10.1590/S0080-623420130000600017

27. Colomé JS, Oliveira DLLC. Educação em saúde: por quem e para quem? a visão de estudantes da graduação em enfermagem. Texto Contexto Enferm. 2012;21(1):177-84. doi: 10.1590/S0104-07072012000100020

28. Martins JJ, Albuquerque GL, Nascimento ERP, Barra DCC, Souza WGA, Pacheco WNS. Necessidade de Educação em saúde dos cuidadores de pessoas idosas no domicílio. Texto Contexto Enferm. 2007; 16(2):254-62. doi: 10.1590/S0104-07072007000200007

29. Ministério da Saúde (BR). Portaria 199 de 30 de Janeiro de 2014. [Internet]. 2014 [cited 2016 Jun 26]. Available from: http://bvsms.saude.gov. br/bvs/saudelegis/gm/2014/prt0199_30_01_2014.html 